supplied with regard to methods for large-scale storage and the grading and sale of bulbs for wholesale or retail trade.

\section{Improvement of Grassland}

THE outstanding work on grassland carried out by the Welsh Plant Breeding Station at Aberystwyth is well known to all specialists of the subject. A definite insight has now been gained into the meaning of the agricultural value of hay and pasture, and the methods by which the desired results may be obtained, even if much more knowledge is still required before adequate control is reached. For the student and farmer, however, much of the published work on the subject is perhaps too elaborate to be of immediate practical use, and the booklet by Prof. R. G. Stapledon entitled "Four Addresses on the Improvement of Grassland" will be welcomed by many (Aberystwyth : University College of Wales, 1933. 1s.). The fundamental aims and methods of grassland management are described in a clear, concise and eminently practical manner. Given a good grass mixture, then judicious grazing and the use of the mowing machine are two of the chief factors upon which success depends, the important part played by the grazing animal being clearly brought out. Where the improvement of land in very poor condition is the problem, the necessity of sowing wild white clover is stressed and the use of some form of phosphatic manure advocated. In fact, the proper balance between grass and clover seems to be the central feature of all good grassland, and in the attainment and maintenance of this optimum ratio by wise choice of mixture, judicious grazing and introduction of wild white clover when needed, the secret of success would seem to lie.

\section{Report on the Science Museum}

In the report for 1932 of the Advisory Council of the Science Museum (London: H.M. Stationery Office), special reference is made to the tuture policy of the Museum, particularly in relation to its utility to industry. With the co-operation of outside bodies, such as the National Physical Laboratory and various research associations, during the past six years special exhibitions have been arranged which have proved attractive not only to the general public but also to technical visitors. At the present time three such exhibitions are being organised annually. A further development of these exhibitions has been suggested in order to afford facilities to an industry or group in an industry, to show inform. atively its products to other industries, and such exhibitions the Council thinks might be of special service to the minor industries now being encouraged in many parts of Great Britain. It is pointed out, however, that here the Museum is handicapped by the want of space, and the Council expresses the hope that the erection of the centre block will soon be taken in hand. The report deals also with the attendances at lectures, the acquisitions, the publications, and with the activities of the Library. In 1931 a sub-committee was appointed to report upon the Library and its working, and among its recommendations was that in the interest of the progress in science and technology and their industrial applications, there is need for a National Library of Science in Great Britain.

\section{Catalogue of Educational Films}

THE issue of a catalogue occupying 184 pages by the Central Information Bureau for Educational Films, is a notable event ("A Guide to Instructional and Educational Films available for Use by Educational and Social Organisations in Great Britain." Pp. vi+184. London: The Central Information Bureau for Educational Films. 3s. 6d.). In the introduction it is stated that this is the first occasion on which a conspectus of the films available for education in Great Britain has been attempted. The present survey is purely quantitative, but the views of educational and social bodies on films found to be of special value are invited. The range of subject matter is very wide and illustrates the great possibilities of films alike as a means of inspiring interest and conveying information. The main sections comprise art, engineering and industry, geography and travel, history, literature, religion and Bible stories, science, social activities and sport. Science alone, however, comprises seven sub-divisions including astronomy, hygiene, nature study and physiology. One might perhaps single out as of special interest the films produced by various scientific institutions and Government departments (such as the Ministry of Agriculture), certain fascinating summaries of scientific research extending over many years, as in the Canti films, films utilising photomicrography, and the really remarkable range of travel films pre. sented. In general, the titles of films are sufficiently descriptive but, where necessary, explanatory paragraphs are added. Films are classified into $35 \mathrm{~mm}$., $16 \mathrm{~mm}$. and $9.5 \mathrm{~mm}$. to suit the financial resources of schools. In an appendix a list of the names and addresses of Government departments, societies and firms mentioned in the catalogue is given.

\section{A Proposed Marine Biological Station in India}

IN Current Science (vol. 1, No. 10, April 1933) it is stated that at a joint session of the Botany and Zoology Sections of the Indian Science Congress recently held at Patna under the presidency of Prof. Gopala Aiyer, the desirability of establishing a Marine Biological Station in India was discussed. Col. Sewell opened the discussion. It was suggested that the authorities of the Science Congress should sanction a certain sum of money which would act as a nucleus for private subscription, and the general opinion was in favour of the station being at Bombay, which with its central position and varied coast line offers an ideal site for such a laboratory. It was moved and seconded that a committee of five biologists be appointed by this joint session of Botany and Zoology Sections of the Indian Science Congress to go into the question of establishing a Marine Biological Station in India and the resolution was carried by a large majority. The committee was constituted as follows : Dr. S. B. Setna, of Bombay (convener), 
Prof. Gopala Aiyer, of Madras, Prof. George Mathai, of Lahore, Prof. R. H. Dastur, of Bombay, and Dr. S. K. Mukerji, of Lucknow.

\section{Co-operation between Science and History}

Voc. 76 of Memoirs and Proceedings of the Manchester Literary and Philosophical Society contains the presidential address of Mr. B. Mouat Jones, in which an appeal is made for co-operation between men of science and historians in the production of the histories for use in elementary and secondary schools and in the universities. He has examined a large number of such books and has found that the influence of scientific thought and discovery on the development of civilisation is unmentioned or unappreciated, or that no attempt is made to incorporate the improvements due to science into the history of the people. He contends that the influence of a scientific advance, such for example as that initiated by Faraday, on the history of the world, is at least as great as some of the movements due to politicians to which historians devote ample space, and he asks that in the books from which the great majority of the population get their historical knowledge, science should be given the place due to it as a determining factor in history.

\section{Memorial to Sir Charles Parsons}

ON July 28, a memorial to Sir Charles Parsons, who died on January 12, 1931 (see NATURE of February 28, 1931) was unveiled at the works of Messrs. C. A. Parsons and Co., Ltd., at Newcastle-on-Tyne by his daughter, Miss Rachel Parsons. The memorial is formed of a medallion portrait of Sir Charles, in profile, carved in Bianca del Mara stone; this is surmounted by the family coat of arms. At the ceremony Miss Parsons said that the memorial was erected on the site of the room in which her father spent so many hours of his life working at the scientific and engineering investigations which appealed to him above everything else. The memorial was designed by Mr. Maurice E. Webb and Mr. Reid Dick was the sculptor.

\section{Priestley Centenary in France}

The issue of the Revue Scientifique for July 8 contains the appreciative address of Prof. C. Matignon, professor of inorganic chemistry in the Collège de France, on the life and work of Priestley, delivered on June 15. In it he reminded his audience that Priestley was elected a foreign associate of the old Royal Academy of Sciences of Paris in 1772, that he was in sympathy with the Revolution of 1790 and that the legislative assembly conferred on him the title "citoyen français" in 1793. Even during the Napoleonic wars, the relations between scientific workers in France and England remained cordial and Davy was awarded the grand prix by the Paris Academy of Sciences in 1807.

\section{Awards of the Royal College of Physicians}

AT the quarterly comitia of the Royal College of Physicians held on July 27, the following awards, among others, were made: the Baly medal to Dr.
Robert Robison, of the Lister Institute, for his work on the esters of phosphoric acid and the enzyme phosphatase and the part they play in bone metabolism ; the Moxon gold medal to Prof. G. R. Minot, professor of clinical medicine in Harvard Medical College, for his work on diseases of the blood; the Weber-Parkes prize and medal for the best work already done in connexion with the etiology, prevention, pathology, or treatment of tuberculosis to Sir John McFadyean. The Leverhulme scholarships held by Dr. J. F. Brock and Dr. S. J. Hartfall have been continued for another year, and the Murchison scholarship was awarded (this year by the University of Edinburgh) to D. M. F. Batty and A. Brown.

\section{Announcements}

Mr. F. E. Magarinos Torres has been appointed director of the Instituto de Meteorologia Hidrometria e Ecologia Agricola at Rio de Janeiro in succession to Prof. Martins Costa, who has resigned.

AT the annual general meeting of the Museums Association, held at Norwich on July 6, it was announced that Dr. Cyril Fox, director of the National Museum of Wales, has been elected president in succession to Sir Henry Miers, and Dr. W. E. Swinton, honorary editor of the Museums Journal. Alderman Chas. Squire, Leicester, and Mr. D. W. Herdman, Cheltenham, were re-elected hon. treasurer and hon. secretary respectively.

Applications are invited for the following appoint. ments, on or before the dates mentioned:-An assistant librarian at the University of CapetownThe Secretary, Office of the High Commissioner for the Union of South Africa, Trafalgar Square, W.C.2 (Aug. 8). A research fellow in glass technology at the University of Sheffield-The Registrar (Aug. 21). An assistant lecturer and demonstrator in electrical engineering at the University of Sheffield-The Registrar (Aug. 25). An assistant lecturer in philosophy at the University of Birmingham-The Secretary (Aug. 28). An assistant lecturer in zoology at the University of Sheffield-The Registrar (Aug. 31). An evening teacher of practical mathematics at the West Ham Municipal College, Romford Road, E.15-The Secretary (Sept. 1). A research chemist at the Long Ashton Fruit Research Station--The Registrar, University of Bristol (Sept. 2). A Univer. sity reader in civil engineering at Imperial College, City and Guilds College-The Academic Registrar, University of London (Sept. 8). A George Henry Lewes student for research at the Physiology School, Cambridge-Prof. Barcroft, Physiology School, Cambridge (Sept. 20). An assistant chemist for the Rubber Research Scheme (Ceylon)-The Chairman, Rubber Research Scheme, Neboda, Ceylon (Oct. 15). A principal of the University College of Wales, Aberystwyth-The President of the College, 44, Queen Victoria Street, London, E.C.4 (Dec. 1). A principal of the Borough Polytechnic, Borough Road, London, S.E.1-The Secretary. An assistant lecturer in education at University College, Hull-The Registrar. 